\title{
TBL2 Gene
}

National Cancer Institute

\section{Source}

National Cancer Institute. TBL2 Gene. NCI Thesaurus. Code C104551.

This gene may be involved in signaling. 